\title{
The Difficulties Experienced by Teachers in the Process of Primary Reading and Writing Instruction and Their Solution Offers for Eliminating These Difficulties
}

\author{
Hatice Değirmenci Gündoğmuş
}

Faculty of Education, Aksaray University, Turkey

Copyright $\mathrm{O} 2018$ by authors, all rights reserved. Authors agree that this article remains permanently open access under the terms of the Creative Commons Attribution License 4.0 International License

\begin{abstract}
The purpose of the current research is to identify the difficulties that primary school teachers experience in the primary reading and writing instruction, and to find out their solution offers for eliminating these difficulties. The study group of the research is composed of 51 primary school teachers selected by criterion sampling as a type of purposive sampling. The qualitative method was used for the research. Semi-structured interviews were made with teachers to ask them three questions. Teacher opinions were taken in writing in order to identify the difficulties which they experienced in the process of primary reading and writing instruction, and thoroughly analyze their opinions about how those difficulties can be solved. The data obtained from these interviews were analysed by the content analysis method. The research revealed that out of the 51 primary school teachers, 37 were happy and 14 were unhappy; the difficulties they described about the process included parental indifference, unreadiness of students, teaching of cursive italic handwriting, lack of professional experience, student absenteeism, lack of interest by students, and physical inadequacies; and their solution offers for eliminating these difficulties included education of parents, carrying out activities suitable for students, change of handwriting type, cooperation with parents, consideration of readiness level, and improvement of physical conditions.
\end{abstract}

Keywords Primary School Teacher, Process of Primary Reading and Writing Instruction, Difficulties, Solution Offers

\section{Introduction}

In today's world, where innovations, changes and improvements are based on knowledge, gaining of effective reading and writing skills plays an important part for individuals to maintain their lives in a better way. As a significant contribution to making one's life meaningful, teaching the skills of reading and reading comprehension is an essential part of training programs and the instruction process [8].

Policymakers of developed countries attach high importance to reading skills, which promote personal development and contribute to improving social level of civilizing. Besides, reading skills are also important in international exams. Developed countries use the PISA (Programme for International Student Assessment), which is supported by OECD (Organization of Economic Cooperation and Development), in order to determine the knowledge and skill levels of their students, compare these with those of the students in other countries, establish standards for increasing national educational levels, and identify the strengths and weaknesses of their national educational systems. In research on PISA, which measures student skills of accessing information in texts, remembering information, interpretation, and expressing one's thoughts, reading literacy is defined as "understanding, using and reflecting on written texts, in order to achieve one's goals, to develop one's knowledge and potential, and to participate in society". The reading literacy results obtained in the PISA 2015 application show that Turkey's general point average is 428 although the average score of all countries is 460 , and that the PISA 2015 reading literacy performance of students in Turkey is lower than that in the PISA 2009 and PISA 2012 [17]. These results demonstrate that the reading literacy of the students in Turkey is below the international average and that there is also a performance decline compared with previous years. In this situation, it is necessary to support activities to be carried out in the field of reading and writing skills, establish standards for improving the quality, and identify and eliminate the deficiencies in the system.

Primary school first grade is the basis of reading and writing instruction. The purpose of the primary reading 
instruction is to teach individuals reading and reading comprehension. Effectiveness of the skills gained in the primary reading instruction is very significant for the future reading and writing performance and academic achievement of individuals. The reading and writing skills not gained in the primary school period, which forms the basis of life, can have serious impacts in later periods [19]. From past to present, primary school teaching has been a holy profession due to the responsibility that it assumes in shaping the future of individuals and even societies by gaining and improving reading and writing literacy.

Effective teachers must adjust their instruction to support student learning and to navigate unpredictable instructional situations to explore the innovative nature of literacy instruction $[4 ; 18 ; 24]$.

Various studies have been done about the primary school teachers experience in the primary reading and writing instruction process $[1 ; 2 ; 5 ; 6 ; 7 ; 13 ; 21 ; 22 ; 26 ; 28]$

Therefore, being a teacher is a broad, multifaceted and complex process [11]. Especially in the early grades, teachers need sound subject knowledge and training in how to teach [23].

In order to improve the quality in the process of reading and writing instruction and ensure that teachers work peacefully, happily and eagerly, it is extremely important to identify the difficulties they experience in the process of primary reading and writing instruction, and find out their solution offers for overcoming these difficulties.

\subsection{Purpose}

The purpose of the research is to identify those difficulties which teachers experience in the process of primary reading and writing instruction, and to reveal their solution offers for eliminating these difficulties. For this purpose, answers were sought for the following questions:

1. Are you happy in the process of reading and writing instruction? Please explain your reason for being or not being happy.

2. What were the problems that you experienced in the process of primary 1 st grade reading and writing instruction?

3. What are your solution offers relating to the problems that you experienced in the process of primary 1 st grade reading and writing instruction?

\section{Methodology}

This section includes information on the design used in the research, participant characteristics, data collection, and analysis.

\subsection{Research Design}

The basic qualitative research design was adopted for this study. "In basic qualitative studies, the overall purpose is to understand how people make sense of their lives and experiences." [16]. Teacher opinions were taken in writing in order to identify the difficulties which they experienced in the process of primary reading and writing instruction, and thoroughly analyze their opinions about how those difficulties can be solved.

\subsection{Study Group}

The study group of the research is composed of 51 primary school teachers who professed primary first grade teaching at least once. Therefore, the criterion sampling method as a type of purposive sampling was utilized in the selection of participants [27]. Demographic characteristics of the study group are given in Table 1 .

Table 1. Demographics of the Participant Teachers

\begin{tabular}{|c|c|c|c|}
\hline Variable & & $\mathrm{f}$ & $\%$ \\
\hline \multirow{4}{*}{ Gender } & Female & 35 & 68,63 \\
\cline { 2 - 4 } & Male & 16 & 31,37 \\
\hline \multirow{4}{*}{$\begin{array}{c}\text { Professional } \\
\text { experience }\end{array}$} & 1 to 5 years & 5 & 9,80 \\
\cline { 2 - 4 } & 6 to 10 years & 9 & 17,65 \\
\cline { 2 - 4 } & 11 to 15 years & 15 & 29,41 \\
\cline { 2 - 4 } & 16 to 20 years & 15 & 29,41 \\
\cline { 2 - 4 } & 21 year or above & 7 & 13,73 \\
\hline \multirow{4}{*}{$\begin{array}{c}\text { Number of teaching } \\
\text { first-graders }\end{array}$} & Once & 6 & 11,76 \\
\cline { 2 - 4 } & 2 times & 7 & 13,73 \\
\cline { 2 - 4 } & 3 times & 12 & 23,53 \\
\cline { 2 - 4 } & 4 times & 12 & 23,53 \\
\cline { 2 - 4 } & 5 times & 6 & 11,76 \\
\cline { 2 - 4 } & 6 times or more & 8 & 15,69 \\
\hline
\end{tabular}

Table 1 shows that $35(68,63 \%)$ teachers were female, and $16(31,37 \%)$ were male, and that that the number of those with a professional experience between 11 and 15 years and between 16 and 20 years $(29,41 \%)$, and of those who taught primary first-graders for 3 to 4 times $(23,53 \%)$ was the highest.

\subsection{Data Collection and Analysis}

Research data were collected by a "semi-structured interview form" that was developed by the researcher using the semi-structured interview technique as one of the interview techniques in the qualitative research approach. The most important facility that the semi-structured interview technique provides is that interviews can be maintained according to a pre-built protocol so that more systematic and comparable data can be obtained [27]. An individually completed question form consisting of three open-ended questions was drawn up, and the participants were requested to complete this form in writing. The content validity of the question form 
was analysed and determined by two academicians who completed their doctorates on, and also professed, primary school teaching. After the questions used in the interview were developed, a pilot experiment was made by applying these to 10 primary school teachers. In the end of the pilot experiment, the questions were deemed to be suitable for the research. Participant privacy rights and that these rights would be respected were stated to the teachers, and then voluntary teachers were included in the study. The participants answered the interview form in about 15 minutes.

The qualitative data obtained were subjected to content analysis. In this technique, similar data are brought together within the frame of certain concepts and themes, and they are arranged so as to be comprehensible by readers, and interpreted. The content analysis technique consists of the stages of data coding, identification of themes, arrangement of codes and themes, and definition and interpretation of findings [27].

In the content analysis of qualitative data, the codes were identified, and categories suitable to those codes were created. Answers by teachers were directly quoted in the content analysis of the data.

In the "Findings" section, the percentage-frequency values of the data were tabularized to demonstrate the rates of opinions. Example statements of the participants relating to the categories created for each question were also provided in the tables.

\subsection{Findings}

This section presents the findings obtained by analysing the data from participant answers given to the questions about the difficulties they experience in the process of primary reading and writing, and their solution offers for eliminating these difficulties. The research findings obtained from participant answers for each question are presented in the tables. For some questions, participant answers can fall to more than one category. Opinions of the participants were brought together under common categories, and percentages, frequency values and relevant statements were presented.

Question 1: "Are you happy in the process of reading and writing instruction? Please explain your reason for being or not being happy."

The answers given by the participants to Question 1 are provided in Table 2 .

Table 2 shows that $37(72,55 \%)$ out of the 51 teachers answered, "Yes, I'm happy", while 14 (27,45\%) said, "No, I'm not happy." The reasons that participants stated for being happy included feeling of teaching, love, and occupational awareness, while their reasons for not being happy included curriculum, the $4+4+4$ system, student related problems, parental indifference, and under-appreciation of teachers.
Table 2. The happiness status of the teachers in the process of reading and writing instruction, and their reasons

\begin{tabular}{|c|c|c|c|}
\hline Happiness Status & Reasons & $\mathbf{f}$ & $\mathbf{\%}$ \\
\hline \multirow{3}{*}{ Yes, I'm happy } & Feeling of teaching & 20 & 39,22 \\
\cline { 2 - 4 } & Love & 13 & 25,49 \\
\cline { 2 - 4 } & Occupational awareness & 2 & 3,92 \\
\hline \multirow{3}{*}{ No, I'm not happy } & No idea stated & 2 & 3,92 \\
\cline { 2 - 4 } & Curriculum & 7 & 13,73 \\
\cline { 2 - 4 } & The 4+4+4 system & 2 & 3,92 \\
\cline { 2 - 4 } & Student related problems & 3 & 5,88 \\
\cline { 2 - 4 } & Parental indifference & 1 & 1,96 \\
\cline { 2 - 4 } & Under-appreciation of teachers & 1 & 1,96 \\
\hline
\end{tabular}

Some of the opinions of those participants who stated that their happiness is derived from feeling of teaching:

"Teaching new things to children who have no knowledge is a great feeling."

"It's a period in which you are rewarded in the best way for your efforts. Change and improvement are noticed the best in this period."

"I'm happy because students begin to read as a result of months of efforts."

"I become happy when I see them read."

"Witnessing their learning to read and write with you, and sharing their joy make one happy."

"I'm happy because of those children who didn't know anything but have learned so much and become eager to learn thanks to me."

Some of the opinions of those participants who stated that their happiness is derived from feeling of love:

"I love children."

"I love children, I love the way they perceive and express life."

"It makes me happy to see students' joy of achievement."

"It gives me happiness to watch children's development."

Some of the opinions of those participants who stated that their happiness is caused by occupational awareness:

"I'm happy because I have an occupation."

Some of the opinions of those participants who stated that their unhappiness is derived from curricular problems:

"Reading and reading comprehension occur slower in the instruction which is based on handwriting and letters compared with the deductive method, that is, the sentence method. This problem reduces the academic achievement of students."

"The curriculum is not student oriented."

"Too many gains are stipulated."

"Handwriting is the problem."

Some of the opinions of those participants who stated that their unhappiness is caused by problems relating to the 4+4+4 system:

"I believe that the 5th grade shouldn't be in the 
secondary school. The one year that children will spend with their primary school teacher is very important."

Some of the opinions of those participants who stated that their unhappiness is caused by student related problems:

"Each new generation is more spoilt and uninterested."

"It's the insufficiency of student readiness."

Some of the opinions of those participants who stated that their unhappiness is derived from parental indifference:

"Indifference of families, failure to get feedback, and support students by reinforcing activities."

Some of the opinions of those participants who stated that their unhappiness is caused by under-appreciation of teachers:

"Teachers are not appreciated."

Question 2: "What were the problems that you experienced in the process of primary 1st grade reading and writing instruction?" The answers given by the participants to Question 2 are presented in Table 3.

Table 3. The difficulties experienced by the teachers in the process of primary reading and writing instruction

\begin{tabular}{|c|c|c|}
\hline Problems & f & $\%$ \\
\hline Parental indifference & 22 & 43,14 \\
\hline Unreadiness of students & 20 & 39,22 \\
\hline Teaching of cursive italic handwriting & 14 & 27,45 \\
\hline Lack of professional experience & 4 & 7,84 \\
\hline Student absenteeism & 2 & 3,92 \\
\hline Lack of interest by students & 1 & 1,96 \\
\hline Physical inadequacies & 1 & 1,96 \\
\hline
\end{tabular}

Table 3 shows that the difficulties experienced by the teachers in the process of primary reading and writing instruction included parental indifference, unreadiness of students, teaching of cursive italic handwriting, lack of professional experience, student absenteeism, lack of interest by students, and physical inadequacies.

Some of the opinions of those participants who believe that the problems experienced in the process of primary reading and writing instruction are mainly caused by parental indifference:

"I've worked in villages, and parental interest is so little, if any."

"Repetition and support at home are insufficient."

"Information taught in the classroom isn't reiterated at home."

"There is no parental support."

"Parents don't provide their children with sufficient support in the writing process."

Some of the opinions of those participants who believe that the problems experienced in the process of primary reading and writing instruction are mainly caused by unreadiness of students:

"Their muscles are not developed enough."

"When writing down things, students' hands get tired fast and therefore they don't want to write."

"Younger students experience difficulty. I believe that children younger than 72 months shouldn't start the first grade."

"Some children can't sufficiently adapt to school physically and mentally"

"The readiness level of students is not sufficient"

"Children's age is too young"

Some of the opinions of those participants who believe that the problems experienced in the process of primary reading and writing instruction are mainly caused by teaching of cursive italic handwriting:

"This handwriting method delays children' learning."

"The handwriting is very difficult and tiresome. Children have difficulty in understanding what they read."

"Students have a hard time with cursive italic handwriting."

Some of the opinions of those participants who believe that the problems experienced in the process of primary reading and writing instruction are mainly caused by lack of professional experience:

"It's the stress and tension of teaching the 1st grade for the first time."

"Levels of students are varied and I don't know what to do."

Some of the opinions of those participants who believe that the problems experienced in the process of primary reading and writing instruction are mainly caused by student absenteeism:

"The problem is, students are absent from school."

"There are many students with the absenteeism problem."

Some of the opinions of those participants who believe that the problems experienced in the process of primary reading and writing instruction are mainly caused by lack of interest by students:

Some of the opinions of those participants who believe that the problems experienced in the process of primary reading and writing instruction are mainly caused by physical inadequacies:

"Classes are too crowded, and technological tools in classes and school are not sufficient."

Question 3: "What are your solution offers relating to the problems that you experienced in the process of primary 1st grade reading and writing instruction?"

The answers given by the participants to Question 3 are presented in Table 4.

Table 4. The solutions offered by the teachers for the problems they experienced in the 1 st grade primary reading and writing instruction process

\begin{tabular}{|c|c|c|}
\hline Solution Offers & $\mathbf{f}$ & $\mathbf{\%}$ \\
\hline Education of parents & 14 & 27,45 \\
\hline Carrying out suitable activities for students & 14 & 27,45 \\
\hline Changing the handwriting & 11 & 21,57 \\
\hline Cooperation with parents & 10 & 19,61 \\
\hline Consideration of student readiness level & 8 & 15,69 \\
\hline Improvement of physical conditions & 2 & 3,92 \\
\hline
\end{tabular}


Table 4 shows that the solutions offered by the teachers against the problems they encountered in the primary reading and writing instruction process include education of parents, carrying out suitable activities for students, change of handwriting, cooperation with parents, consideration of student readiness level, and improvement of physical conditions.

Some of the opinions of those participants who offer education of parents as a solution for the problems experienced in the process of primary reading and writing instruction:

"Parents should be educated."

"Parental education programs should be organized."

"It's necessary to primarily educate parents, tell them the situation, and inform them about the process."

"Parent awareness should be raised by organizing seminars."

Some of the opinions of those participants who offer carrying out suitable activities for students as a solution for the problems experienced in the process of primary reading and writing instruction:

"Books utilizing basic straight letters can be more attractive. In the Turkish language book, a reading piece is four pages long and this is too much for a child who newly learns reading. Texts must be shortened and simplified."

"Reading activities and dictation should be performed frequently. Children's vocabulary should be enriched."

"Different activities should be prepared to enable children to develop their creativity."

Some of the opinions of those participants who offer change of handwriting as a solution for the problems experienced in the process of primary reading and writing instruction:

"We needed to leave the cursive handwriting."

"Basic straight letters should be used in writing."

"The decree repealing cursive handwriting is on the mark."

"I think that the process will now be easier with the cancellation of the cursive handwriting."

Some of the opinions of those participants who suggest cooperation with parents as a solution for the problems experienced in the process of primary reading and writing instruction:

"Reading and writing instruction is a process, and students can't be expected to learn things only in school, their families should also have the necessary care for them."

"Parent-teacher cooperation should be secured."

"It's necessary to engage parents in the reading and writing process as well by increasing parent-teacher cooperation."

"It's essential to ensure parent-teacher cooperation."

"A strong communication with families is extremely important. Enthusiastically sharing even the slightest achievement and progress with the student and their family will help overcome problems."

Some of the opinions of those participants who offer consideration of student readiness level as a solution for the problems experienced in the process of primary reading and writing instruction:

"Primarily, schooling age should be determined logically according to children's developmental stages, and it should be ensured that all children have preschool education."

"Students who haven't attended kindergarten should not start the first grade."

"All students should go to kindergarten and they shouldn't be younger than 72 months."

"Kindergarten should be compulsory."

Some of the opinions of those participants who suggest improvement of physical conditions as a solution for the problems experienced in the process of primary reading and writing instruction:

"Class sizes should be diminished and we should be supplied with materials that we can use in the process of reading and writing instruction."

"Classrooms shall be equipped technologically."

\section{Conclusions, Discussion and Suggestions}

The role of the teachers in improving the primary reading and writing instruction process is very important. In today's classrooms, a thoughtful and flexible approach to literacy instruction is required [25].

It is essential that teachers work in an environment where they feel self-confident, can express themselves, their demands and opinions are regarded, and are provided with an opportunity to express the difficulties they experience in order to increase their performance in the process of reading and writing literacy education, which is a difficult and rewarding experience for teachers [11], and to ensure that they can work happily in this process.

The current research finds that 37 of the participant teachers are happy and 14 are unhappy in the process of reading and writing instruction. They stated their reason for being happy as feeling of teaching, love, and occupational awareness, while their reasons for not being happy included curriculum, the $4+4+4$ system, student related problems, parental indifference, and under-appreciation of teachers. The difficulties they experience in the process included parental indifference, unreadiness of students, teaching of cursive italic handwriting, lack of professional experience, student absenteeism, lack of interest by students, and physical inadequacies; and their solution offers for eliminating these difficulties included education of parents, carrying out activities suitable for students, change of handwriting type, cooperation with parents, consideration of readiness level, and improvement of physical conditions. 
It draws attention that the teachers mainly highlighted parental indifference and education of parents. Studies by Çatak Gülbaş [8] and Kaya and Taşdemirci [14] reading and writing instruction, and suggested that Kaya and Taşdemirci [14] also addressed parental indifference in the primary cooperation with parents should be improved.

As regards cursive italic handwriting, which the participant teachers accentuated in relation to the difficulties encountered in the process of primary reading and writing instruction and overcoming these difficulties, Çatak Gülbaş [8] reports that teachers are hesitant about cursive italic handwriting and that the use of basic straight letters is easier, while Şahin [20] and Gün [12] argue that teachers do not generally encounter problems with the teaching of cursive italic handwriting.

As regards level of readiness that was emphasized by the participant teachers $[9 ; 15]$ demonstrated that most of their participants had a negative opinion about first graders starting school at an early age. Erkan and Kirca [10] reported that children's starting school before reaching readiness level resulted in inefficacy and emotional exhaustion.

In the light of all these findings, the difficulties expressed by teachers, who are the implementers of the process of primary reading and writing instruction, should be taken into account in order to improve the quality of the process. In this context, in-depth studies should be made on the subject matters which teachers perceive as problems and about which they share solution offers, and results of these studies should be shared with them. Teachers should be informed about activities to be performed about these processes.

\section{REFERENCES}

[1] Akman, E., \& Aşkın, İ. (2012). Ses temelli cümle yöntemine eleştirel bir bakış. Gazi Üniversitesi Gazi Eğitim Fakültesi Dergisi. 32 (1), 1-18.

[2] Aktürk, Y., \& Mentiş Taş, A. (2011). İlk okuma-yazma öğretiminde "ses temelli cümle yöntemi"nin uygulanmasına ilişkin öğretmen görüşleri (şanlıurfa/viranşehir örneği). Adnan Menderes Üniversitesi Eğitim Fakültesi Eğitim Bilimleri Dergisi, 2 (1), 27-37.

[3] Akyol, H. (2010). Yeni Programa Uygun Türkçe Öğretim Yöntemleri (3. Bask1). Ankara: Pegem Akademi.

[4] Allen, M. H., Matthews, C. E., \& Parsons, S. A. (2013). A second-grade teacher's adaptive teaching during an integrated science-literacy unit. Teaching and Teacher Education, 35, 114-125.

[5] Babayiğit, Ö., \& Erkuş, B. Problems and Solutions in Literacy Training Process. Erzincan Üniversitesi Ĕ̈itim Fakültesi Dergisi, 19, 2, 271-284.

[6] Başar, M. (2013). 60-66 ay aralığında ilkokula başlayan öğrencilerin kişisel öz bakım ve ilkokuma-yazma becerilerinin öğretmen görüşlerine göre değerlendirilmesi. Turkish Studies. 8 (8), 241-252.

[7] Bektaş, A. (2007). Ses temelli cümle yöntemiyle gerçekleştirilen ilk okuma-yazma öğretiminin değerlendirilmesi. Yüksek Lisans Tezi. Çukurova Üniversitesi Sosyal Bilimler Enstitüsü. Adana.

[8] Çatak Gülbaș, C. (2008). Yeni İlköğretim 1. Sinıf İlkokuma Yazma Dersi Ögretim Programı Uygulanmasina Yönelik Öğretmen Görüşleri. (Yayınlanmamış Yüksek Lisans Tezi). Muğla Üniversitesi/Sosyal Bilimler Enstitüsü, Muğla.

[9] Epçaçan, C. (2014). İlkokul ve ortaokul öğretmen ve yöneticilerinin $4+4+4$ eğitim sistemine ilişkin görüşleri (Siirt ili örneği). Ekev Akademi Dergisi, 18 (58), 505-522.

[10] Erkan, S. ve Kırca, A. (2010). Okul öncesi eğitimin ilköğretim birinci sınıf öğrencilerinin okula hazır bulunuşluklarına etkisinin incelenmesi. Hacettepe Üniversitesi Ĕ̌itim Fakültesi Dergisi, 38, 94-106

[11] Flores, M. A., \& Day, C. (2006). Contexts which shape and reshape new teachers' identities: A multi-perspective study. Teaching and Teacher Education, 219-232.

[12] Gün, A. (2006). Öğretmenlerin Ses Temelli Cümle Yöntemine İlişkin Algıları ve Görüşleri. Yayımlanmamış yüksek lisans tezi, Dokuz Eylül Üniversitesi Eğitim Bilimleri Enstitüsü, İzmir.

[13] Gündüz, F., \& Çalışkan, M. (2013). 60-66, 66-72, 72-84 aylık çocukların okul olgunluk ve okuma yazma becerilerini kazanma düzeylerinin incelenmesi. Turkish Studies. 8 (8), 379-398.

[14] Kaya, K. ve Taşdemirci, E. (2005). Birleştirilmiş Sınıflar İle Bağımsız Sınıflarda İlkokuma Yazma Öğretiminde Karşılaşılan Sorunların Karşılaştırılmalı İncelenmesi. Sosyal Bilimler Enstitüsü Dergisi, 2, 1-26.

[15] Memişoğlu, S.P. ve İsmetoğlu, M. (2013). Zorunlu Eğitimde 4+4+4 Uygulamasına İlişkin Okul Yöneticilerinin Görüşleri. Ĕ̈itim ve Ögretim Araştırmaları Dergisi, 2(2), 14-25.

[16] Merriam, S. B. (2013). Nitel araştırma. Desen ve Uygulama İçin Bir Rehber. (Çev. Ed.: Selahattin Turan). Ankara: Nobel Akademik Yayıncılık.

[17] Millî Eğitim Bakanlığı, (2016). PISA 2015 Ulusal Raporu. Web: http://pisa.meb.gov.tr/wp-content/uploads/2014/11/PISA20 15_UlusalRapor.pdf 10.11.2017

[18] Parsons, S. A. (2012). Adaptive teaching in literacy instruction: Case studies of two teachers. Journal of Literacy Research, 44(2), 149-170.

[19] Stanovich, K. E. (1986). Matthew Effects İn Reading: Some Consequences Of İndividual Differences İn The Acquisition Of Literacy. Reading Research Quarterly, 21, 360-407

[20] Şahin, A. (2012). Bitişik Eğik Yazı Öğretiminde Karşılaşılan Problemler. Eğitim ve Bilim Dergisi, (37)165; 167-178.

[21] Şahin, İ., İnci, S., Turan, H., \& Apak, Ö. (2006). İlk okuma öğretiminde ses temelli cümle yöntemiyle çözümleme yönteminin karşılaştırılması. Millî Eğitim. Sayı 171. 109-129.

[22] Tok, Ş., Tok, N. T., \& Mazı, A. (2008). İlkokuma yazma 
öğretiminde çözümleme ve ses temelli cümle yöntemlerinin değerlendirilmesi. Kuram ve Uygulamada Eğitim Yönetimi. Say1 53, 123-144.

[23] United Nations Educational, Scientific and Cultural Organization (UNESCO). (2014). Teaching and learning: achieving quality for all.

[24] Vaughn, M., \& Parsons, S. A. (2013). Adaptive teachers as innovators: Instructional adaptations opening spaces for enhanced literacy learning. Language Arts, 91(2), 81-93.

[25] Vaughn M, Parsons SA, Gallagher MA, Branen J (2015). Teachers' adaptive instruction supporting students' literacy learning. Reading Teacher International Literacy Association. 69(5):539-547.
[26] Yıldırım, M. (2008). Birleștirilmiş sinıflı ilköğretim okullarında ses temelli cümle ögretimi yöntemi ile ilk okuma yazma öğretimi sırasında karşılaşılan güçlükler. Yüksek Lisans Tezi. Çukurova Üniversitesi Sosyal Bilimler Enstitüsü. Adana.

[27] Yıldırım, A., \& Şimşek, H. (2011). Sosyal bilimlerde nitel araştirma yöntemleri. Ankara: Seçkin Yayıncılık.

[28] Yiğit, V. (2009). Ses temelli cümle yöntemi ile ilk okuma yazma öğretim sürecinde karşılaşılan güçlükler ve bu güçlüklerle baş etme stratejilerinin belirlenmesi; (şırnak ili örneği). Yüksek Lisans Tezi. Çukurova Üniversitesi Sosyal Bilimler Enstitüsü. Adana. 